\title{
A systematic review of individual patient data meta-analyses on surgical interventions
}

\author{
Gerjon Hannink ${ }^{1 *}$, Hein G Gooszen ${ }^{1}$, Cornelis JHM van Laarhoven² and Maroeska M Rovers ${ }^{1,3}$
}

\begin{abstract}
Background: Compared to subgroup analyses in a single study or in a traditional meta-analysis, an individual patient data meta-analysis (IPDMA) offers important potential advantages. We studied how many IPDMAs report on surgical interventions, how many of those surgical IPDMAs perform subgroup analyses, and whether these subgroup analyses have changed decision-making in clinical practice.

Methods: Surgical IPDMAs were identified using a comprehensive literature search. The last search was conducted on 24 April 2012. For each IPDMA included, we obtained information using a standardized data extraction form, and the quality of reporting was assessed. We also checked whether results were implemented in clinical guidelines.
\end{abstract}

Results: Of all 583 identified IPDMAs, 22 (4\%) reported on a surgical intervention. Eighteen (82\%) of these IPDMAs presented subgroup analyses. Subgroups were mainly based on patient and disease characteristics. The median number of reported subgroup analyses was 3.5 (IQR 1.25-6.5). Statistical methods for subgroup analyses were mentioned in 11 (61\%) surgical IPDMAs.

Eleven (61\%) of the 18 IPDMAs performing subgroup analyses reported a significant overall effect estimate, whereas six (33\%) reported a non-significant one. Of the IPDMAs that reported non-significant overall results, three IPDMAs (50\%) reported significant results in one or more subgroup analyses. Results remained significant in one or more subgroups in eight of the IPDMAs (73\%) that reported a significant overall result.

Eight (44\%) of the 18 significant subgroups appeared to be implemented in clinical guidelines. The quality of reporting among surgical IPDMAs varied from low to high quality.

Conclusion: Many of the surgical IPDMAs performed subgroup analyses, but overall treatment effects were more often emphasized than subgroup effects. Although, most surgical IPDMAs included in the present study have only recently been published, about half of the significant subgroups were already implemented in treatment guidelines.

\section{Background}

Surgery has advanced spectacularly in the past 50 years, but many advances have not come from carefully planned research using valid study designs [1]. Research on surgical interventions is associated with several methodological and practical challenges of which few, if any, apply only to surgery. Surgical innovation is especially demanding because many of these challenges coincide [2]. Perhaps this situation leads many surgeons to view randomized controlled trials (RCTs), although theoretically advantageous, to be too difficult and impractical to

\footnotetext{
* Correspondence: g.hannink@orthop.umcn.nl

'Department of Operating Rooms, Radboud University Nijmegen Medical Center, PO Box 9101, Nijmegen 6500HB, The Netherlands

Full list of author information is available at the end of the article
}

undertake, and even worse, irrelevant to their practice because of concerns about generalizability $[2,3]$.

The results of RCTs are usually implemented in practice by either treating or testing all patients in case of a 'positive' study or treating or testing no-one in case of a 'negative' study. Clinicians intuitively know that this approach is oversimplified because in reality some patients benefit more than average whereas others do not benefit. This may explain why around $50 \%$ of the RCTs perform subgroup analyses [4,5]. However, misleading claims about subgroup effects based on a single study are common [6].

Investigating subgroups is a highly relevant, but complex topic because of two interrelated concerns: failure to detect a relevant subgroup effect (false negative), and

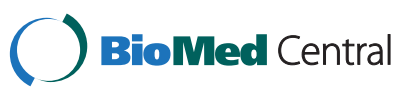


a misleading claim about a subgroup effect which in reality does not exist (false positive). Both of these problems can lead to suboptimal care for patients. Subgroup effects have been extensively and fiercely debated in the clinical, epidemiological, and statistical literature, especially in the context of single trials or traditional metaanalyses based on published summary results [7-11].

Individual patient data meta-analyses (IPDMAs) differ from traditional meta-analyses in that an IPD metaanalysis uses the 'raw data' of individual patients from included studies instead of the published summary results of studies in a traditional meta-analysis [12]. Compared to subgroup analyses in a single study or in a traditional meta-analysis, an IPDMA offers important potential advantages, such as: (1) increased possibilities to perform more complex statistical analyses that better match the underlying data; (2) more power compared to single studies and traditional meta-analyses; (3) higher validity of subgroup analyses by avoiding ecological bias and by taking the distribution of other patient characteristics into account; (4) improved flexibility and standardization of defining subgroups across studies; and (5) opportunities to examine the consistency of subgroup effects across studies [13-17].

In this paper we present a systematic overview of all IPDMAs on surgical interventions published. We studied the number and types of subgroup analyses performed, and whether these subgroups analyses influenced decision-making in clinical practice.

\section{Methods}

\section{Search}

A comprehensive literature search in PubMed, Embase, Web of Science, and the Cochrane Library was conducted to identify all IPDMAs of RCTs. The last search was conducted on 24 April 2012. Keywords used to develop our search strategy were 'individual patient data' and 'meta-analysis' (see Additional file 1 for detailed search strategy).

\section{Selection}

In first instance, titles and abstracts were screened to identify eligible IPDMAs. Selection of potential eligible IPDMAs was restricted to IPD obtained from RCTs comparing surgical interventions. Patients had to be randomized over a surgical intervention in at least one treatment arm, and the surgical procedures had to be performed under general, spinal, epidural, or regional anesthesia. IPDMAs regarding drug-eluting medical devices and surgical trials in which a drug was the comparison were excluded.

Full text papers were retrieved when meta-analytic techniques for individual patient data of RCTs were used. IPDMAs using the same dataset or combination of datasets, studying/addressing different questions/ subgroups were included. If obvious duplicate papers were available, the most elaborate paper was included.

\section{Data extraction and analysis}

Data from all included surgical IPDMAs were extracted with respect to specific characteristics, that is, publication year, number of included trials and patients, domain, type of intervention, comparison, and outcome measured. Regarding the subgroups, number, type, justification, statistical methods, and results in relation to the overall effect estimate were studied.

We classified five types of subgroups, patient characteristics (for example, age or gender), disease characteristics (for example, severity or co-morbidity), household characteristics (for example, socioeconomic status or smoking), intervention characteristics (for example, type of intervention or dose), and methodological characteristics (for example, quality of included trials or trial effect). Justification for subgroups analyses was categorized as based on literature, clinical experience, biological mechanism, or no justification.

We also assessed the quality of reporting of all selected IPDMAs. IPDMAs on RCTs should be reported according to the Preferred Reporting Items for Systematic Reviews and Meta-Analyses (PRISMA) [18]. Since this guideline is not specific to IPDMAs, it has been suggested that some additional information should be reported, for instance why the IPDMA approach was initiated, whether there was a protocol for the IPDMA project, and whether a one-step or a two-step analysis was performed [12]. We judged the quality of reporting based on the 18 criteria suggested by Riley et al. [12]. Two independent reviewers (GH and MMR) selected eligible surgical IPDMAs and extracted data (duplicate independently). Any disagreements were resolved by consensus.

Finally, we reviewed available clinical guidelines for recommendations based on significant results of subgroup analyses from IPDMAs to determine the extent to which these results were implemented in clinical guidelines. We conducted a PubMed search for fields 'patients' (for example, carotid stenosis), 'intervention' (for example, carotid stenting) and 'comparison' (for example, endarterectomy), extracted from IPDMAs with significant subgroup analyses, and limited our search to 'Practice Guideline'. We only included publications in English. We also searched the National Library of Guidelines (http://guidance.nice.org.uk/), and the National Guideline Clearinghouse (http://www.guidelines. gov/).

All steps in this review were carried out according to a pre-defined protocol (Additional file 2). 


\section{Results}

Search

In the search for IPDMAs, 3,597 potential eligible papers were identified. After studying the abstracts, 583 papers, published between 1991 and 2012, indeed reported an IPDMA. After detailed evaluation, 22 (4\%) IPDMAs reported on a surgical intervention and met our inclusion criteria (Figure 1; Additional file 3).

Of the 22 surgical IPDMAs, 12 focused on cardiovascular interventions, three on inguinal hernia repair, three on gynecological interventions, two on orthopedic interventions, one on a gastroenterological intervention, and one on ventilation tubes for otitis media (Table 1). The surgical IPDMA papers were published between 2005 and 2012. Eighteen (82\%) of the 22 surgical IPDMAs tried to identify subgroups of patients that benefit more or less from the surgical intervention.
The remaining non-surgical IPDMAs predominantly focused on cancer, cardiovascular disease, and diabetes, and most assessed whether a treatment or intervention was effective, often in subgroups of patients. Before 2000 only a few IPDMAs were published, whereas a considerable rise in the number of published IPDMAs is seen between 2005 and 2012 (Figure 2). This growth is most likely the result of an increased awareness the potential advantages of IPDMAs, and the initiation of collaborations to specifically perform such studies.

\section{Summary of IPDMAs using IPD (or part of IPD) from the} same trials

Of the 12 IPDMAs that focused on a cardiovascular intervention, four IPDMAs [26-29] used individual patient data from the same 22 trials (6,763 patients) evaluating the clinical effects of primary percutaneous coronary

3,597 records identified through database searching

- PublMed 2,015 records

- Embase 921 records

- Web of Science 522 records

- Cochrane Library 139 records

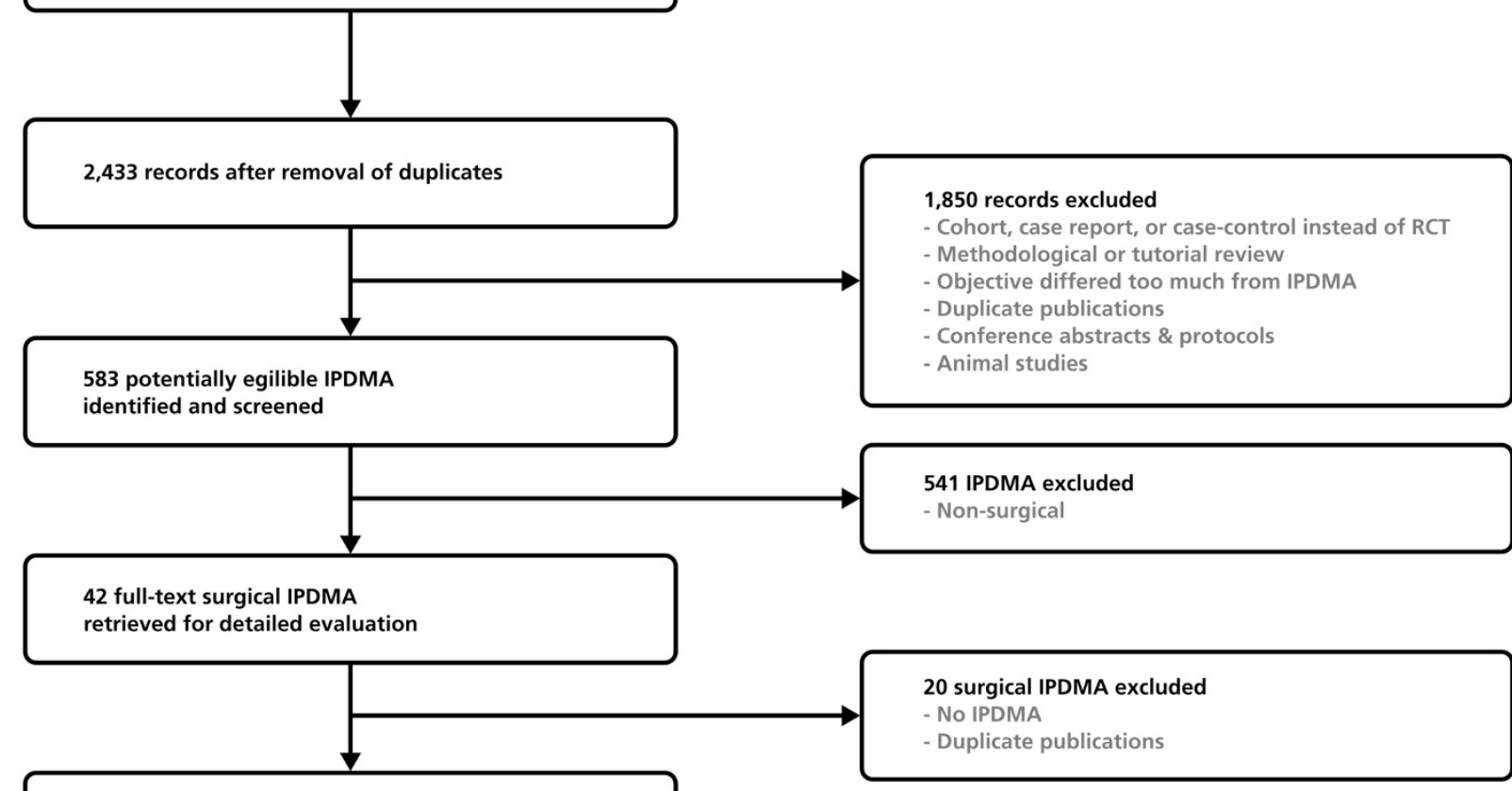

22 surgical IPDMA included

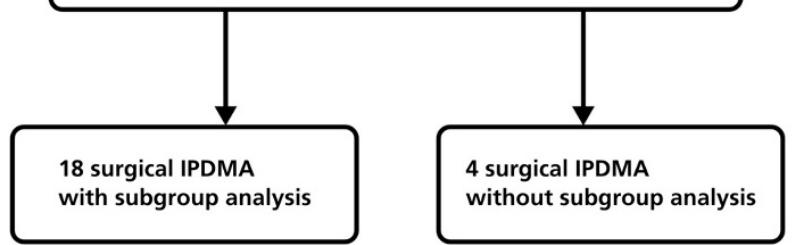

Figure 1 Flowchart of study selection process for IPDMA of surgical interventions. 
Table 1 Characteristics of the $\mathbf{2 2}$ identified surgical IPDMAs

\begin{tabular}{|c|c|c|c|c|c|c|c|c|c|}
\hline Author and year & $\begin{array}{l}\text { RCTs } \\
(n)\end{array}$ & $\begin{array}{l}\text { Patients } \\
(n)\end{array}$ & Patients & Intervention & Comparison & Outcome & Subgroups $(n)$ & $\begin{array}{l}\text { Overall } \\
\text { effect } \\
\text { estimate }\end{array}$ & $\begin{array}{l}\text { Significant } \\
\text { effect } \\
\text { estimates } \\
\text { in } \\
\text { subgroups } \\
(n / N)\end{array}$ \\
\hline \multirow{4}{*}{$\begin{array}{l}\text { Jorgenson et al., } 2007 \\
\text { [19] }\end{array}$} & \multirow[t]{4}{*}{7} & \multirow[t]{4}{*}{2,091} & \multirow{4}{*}{$\begin{array}{l}\text { Women with } \\
\text { cervical } \\
\text { insufficiency }\end{array}$} & \multirow[t]{4}{*}{ Cervical cerclage } & \multirow{4}{*}{$\begin{array}{l}\text { Expectant } \\
\text { management, no } \\
\text { cerclage }\end{array}$} & Primary & \multirow{4}{*}{$\begin{array}{l}\text { Obstetric history, cervical length } \\
\text { (2) }\end{array}$} & \multirow[t]{4}{*}{ NS } & \multirow[t]{4}{*}{$0 / 2$} \\
\hline & & & & & & $\begin{array}{l}\text { Pregnancy loss or neonatal death } \\
\text { before discharge from hospital }\end{array}$ & & & \\
\hline & & & & & & Secondary & & & \\
\hline & & & & & & $\begin{array}{l}\text { Preterm delivery and maternal } \\
\text { morbidity }\end{array}$ & & & \\
\hline Hlatky et al., 2009 [20] & 10 & 7,812 & $\begin{array}{l}\text { Patients with } \\
\text { multivessel } \\
\text { coronary disease }\end{array}$ & $\begin{array}{l}\text { Coronary artery } \\
\text { bypass graft }\end{array}$ & $\begin{array}{l}\text { Percutaneous } \\
\text { coronary } \\
\text { intervention }\end{array}$ & All-cause mortality & $\begin{array}{l}\text { Age, sex, diabetes, smoking, } \\
\text { hypertension, } \\
\text { hypercholesterolaemia, PVD, } \\
\text { stability of symptoms, previous } \\
\text { Ml, heart failure, LV function, no. } \\
\text { of diseased vessel, proximal LAD, } \\
\text { balloon vs.stent (14) }\end{array}$ & NS & $2 / 14$ \\
\hline $\begin{array}{l}\text { Daniels et al., } 2010 \\
\text { [21] }\end{array}$ & 5 & 862 & $\begin{array}{l}\text { Patients with } \\
\text { chronic pelvic } \\
\text { pain }\end{array}$ & $\begin{array}{l}\text { Laparoscopic } \\
\text { uterosacral nerve } \\
\text { ablation (LUNA) }\end{array}$ & No LUNA & $\begin{array}{l}\text { Derived measure of worst pain } \\
\text { level experienced }\end{array}$ & $\begin{array}{l}\text { Presence of visual pathology, site } \\
\text { of pain, age, parity (4) }\end{array}$ & NS & $1 / 4$ \\
\hline \multirow{4}{*}{$\begin{array}{l}\text { Burzotta et al., } 2009 \\
\text { [22] }\end{array}$} & \multirow[t]{4}{*}{11} & \multirow[t]{4}{*}{2,686} & \multirow{4}{*}{$\begin{array}{l}\text { Patients with ST- } \\
\text { elevation } \\
\text { myocardial } \\
\text { infarction (STEMI) }\end{array}$} & \multirow{4}{*}{$\begin{array}{l}\text { Percutaneous } \\
\text { coronary } \\
\text { intervention with } \\
\text { thrombectomy }\end{array}$} & \multirow{4}{*}{$\begin{array}{l}\text { Standard } \\
\text { percutaneous } \\
\text { coronary } \\
\text { intervention }\end{array}$} & Primary & \multirow{4}{*}{$\begin{array}{l}\text { Manual vs. non-manual } \\
\text { thrombectomy devices, diabetes, } \\
\text { primary vs. rescue PCI, treated vs. } \\
\text { non-treated with Ilb/llla-inhibitors, } \\
\text { ischemic time, infarct-related } \\
\text { artery, pre-PCI TIMI flow (7) }\end{array}$} & \multirow[t]{4}{*}{ S } & \multirow[t]{4}{*}{$1 / 7$} \\
\hline & & & & & & All-cause mortality & & & \\
\hline & & & & & & Secondary & & & \\
\hline & & & & & & $\begin{array}{l}\text { Survival free from MI, TLR, or TVR, } \\
\text { major adverse coronary events } \\
\text { (MACE), death+Ml }\end{array}$ & & & \\
\hline \multirow{4}{*}{$\begin{array}{l}\text { Carotid Stenting } \\
\text { Trialists'Collaboration, } \\
2010 \text { [23] }\end{array}$} & \multirow[t]{4}{*}{3} & \multirow[t]{4}{*}{3,433} & \multirow{4}{*}{$\begin{array}{l}\text { Patients with } \\
\text { symptomatic } \\
\text { carotid stenosis }\end{array}$} & \multirow[t]{4}{*}{ Carotid stenting } & \multirow[t]{4}{*}{ Endarterectomy } & Primary & \multirow{4}{*}{$\begin{array}{l}\text { Age, sex, diabetes, hypertension, } \\
\text { SBP, hypercholesterolaemia, } \\
\text { smoking, coronary heart disease, } \\
\text { peripheral artery disease, most } \\
\text { recent ipsilateral ischemic event, } \\
\text { history of stroke, degree of } \\
\text { ipsilateral ischemic stroke, } \\
\text { contralateral severe carotid } \\
\text { stenosis or occlusion, treatment } \\
\text { within } 14 \text { days, patients recruited } \\
\text { per center, center recruitment } \\
\text { rate (16) }\end{array}$} & \multirow[t]{4}{*}{ S } & \multirow[t]{4}{*}{$1 / 16$} \\
\hline & & & & & & Any stroke or death & & & \\
\hline & & & & & & Secondary & & & \\
\hline & & & & & & $\begin{array}{l}\text { Disabling stroke or death, all- } \\
\text { cause death, any stroke, } \\
\text { myocardial infarction, severe local } \\
\text { hematoma, severe wound } \\
\text { infection }\end{array}$ & & & \\
\hline $\begin{array}{l}\text { Middleton et al., } 2010 \\
\text { [24] }\end{array}$ & 17 & 2,814 & $\begin{array}{l}\text { Patients with } \\
\text { heavy menstrual } \\
\text { bleeding }\end{array}$ & $\begin{array}{l}\text { Hysterectomy, } \\
\text { endometrial } \\
\text { destruction (1st \& } \\
\text { 2nd generation), } \\
\text { levonorgestrel }\end{array}$ & $\begin{array}{l}\text { Endometrial } \\
\text { destruction (1st \& } \\
\text { 2nd generation), } \\
\text { levonorgestrel } \\
\text { releasing intra- }\end{array}$ & Dissatisfaction rates & $\begin{array}{l}\text { Uterine cavity length, age, } \\
\text { presence of fibroids/polyps, } \\
\text { parity, baseline bleeding score (5) }\end{array}$ & S & $1 / 5$ \\
\hline
\end{tabular}


Table 1 Characteristics of the 22 identified surgical IPDMAs (Continued)

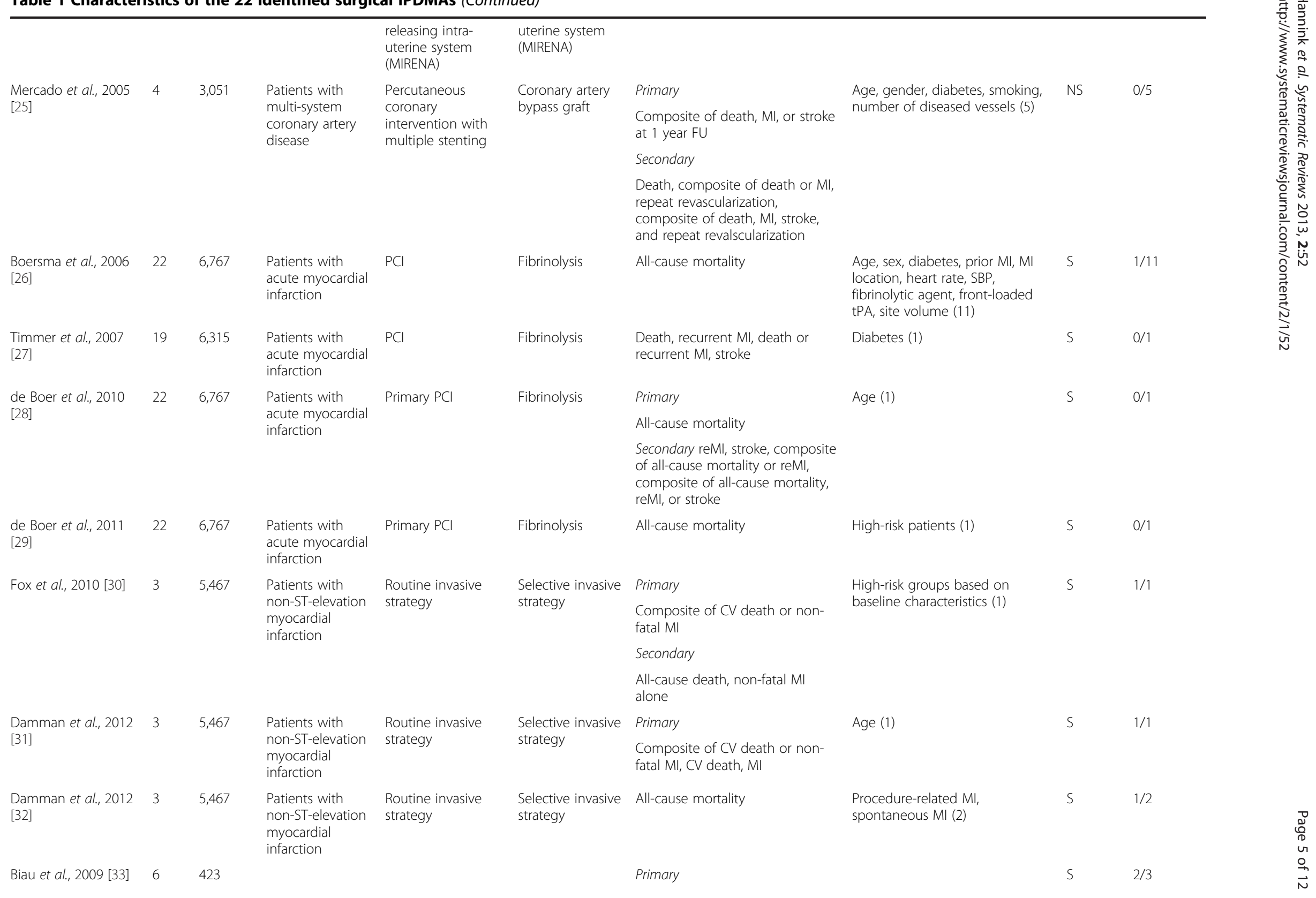


Table 1 Characteristics of the 22 identified surgical IPDMAs (Continued)

\begin{tabular}{|c|c|c|c|c|c|c|c|c|c|}
\hline & & & \multirow{2}{*}{$\begin{array}{l}\text { Patients with } \\
\text { symptomatic } \\
\text { unilateral anterior } \\
\text { cruciate ligament } \\
\text { injury }\end{array}$} & \multirow{2}{*}{$\begin{array}{l}\text { Reconstruction with } \\
\text { patellar tendon } \\
\text { autograft }\end{array}$} & \multirow{2}{*}{$\begin{array}{l}\text { Reconstruction } \\
\text { with hamstring } \\
\text { tendon autograft }\end{array}$} & Positive pivot-shift test Secondary & \multirow{2}{*}{$\begin{array}{l}\text { Gender, age at surgery, trial effect } \\
\text { (3) }\end{array}$} & & \\
\hline & & & & & & Positive Lachman test & & & \\
\hline $\begin{array}{l}\text { Rovers et al., } 2005 \\
{[34]}\end{array}$ & 7 & 1,234 & $\begin{array}{l}\text { Children with } \\
\text { otitis media with } \\
\text { effusion }\end{array}$ & $\begin{array}{l}\text { Short-term } \\
\text { ventilation tubes }\end{array}$ & Watchful waiting & $\begin{array}{l}\text { Mean time spent with effusion, } \\
\text { hearing, language development }\end{array}$ & $\begin{array}{l}\text { Hearing level at baseline, history } \\
\text { of acute otitis media, upper } \\
\text { respiratory infections, attending } \\
\text { day care, socioeconomic status, } \\
\text { siblings, season, history of } \\
\text { breastfeeding, parental smoking } \\
\text { (9) }\end{array}$ & NS & $2 / 9$ \\
\hline \multirow{4}{*}{$\begin{array}{l}\text { Salerno et al., } 2007 \\
\text { [35] }\end{array}$} & \multirow[t]{4}{*}{4} & \multirow[t]{4}{*}{305} & \multirow{4}{*}{$\begin{array}{l}\text { Cirrhotic patients } \\
\text { with refractory } \\
\text { ascites }\end{array}$} & \multirow{4}{*}{$\begin{array}{l}\text { Transjugular } \\
\text { intrahepatic } \\
\text { portosystemic shunt } \\
\text { (TIPS) }\end{array}$} & \multirow[t]{4}{*}{ Paracentesis } & Primary & \multirow[t]{4}{*}{ NA } & \multirow[t]{4}{*}{ S } & \multirow[t]{4}{*}{ NA } \\
\hline & & & & & & Death from any cause before $L T$ & & & \\
\hline & & & & & & Secondary & & & \\
\hline & & & & & & Liver-related death & & & \\
\hline $\begin{array}{l}\text { Staples et al., } 2011 \\
\text { [36] }\end{array}$ & 2 & 209 & $\begin{array}{l}\text { Patients with } \\
\text { osteoporotic } \\
\text { vertebral } \\
\text { compression } \\
\text { fractures }\end{array}$ & Vertebroplasty & Sham & Scores for pain and function & $\begin{array}{l}\text { Onset of pain, pain scores at } \\
\text { baseline (2) }\end{array}$ & NS & $0 / 2$ \\
\hline \multirow{2}{*}{$\begin{array}{l}\text { McCormack et al., } \\
2003[37]\end{array}$} & \multirow[t]{2}{*}{25} & \multirow[t]{2}{*}{4,165} & \multirow[b]{2}{*}{$\begin{array}{l}\text { Patients with } \\
\text { clinical diagnosis } \\
\text { of groin hernia } \\
\text { for whom } \\
\text { surgical } \\
\text { management was } \\
\text { judged } \\
\text { appropriate }\end{array}$} & Laparoscopic repair & \multirow[t]{2}{*}{ Open repair } & \multirow[b]{2}{*}{$\begin{array}{l}\text { Duration of operation, 'opposite' } \\
\text { method initiated, conversion, } \\
\text { hematoma, seroma, wound/ } \\
\text { superficial infection, mesh/deep } \\
\text { infection, port site hernia, vascular } \\
\text { injury, visceral injury, length of } \\
\text { hospital stay, time to return to } \\
\text { usual activities, persisting pain, } \\
\text { persisting numbness, hernia } \\
\text { recurrence, known death within } \\
30 \text { days of surgery }\end{array}$} & \multirow[t]{2}{*}{ NA } & \multirow[t]{2}{*}{ S } & \multirow[t]{2}{*}{ NA } \\
\hline & & & & $\begin{array}{l}\text { (Transabdominal } \\
\text { preperitoneal repair } \\
\text { (TAPP) or totally } \\
\text { extraperitoneal } \\
\text { repair (TEP)) }\end{array}$ & & & & & \\
\hline Scott et al., 2002 [38] & 11 & 3,347 & $\begin{array}{l}\text { Patients with } \\
\text { clinical diagnosis } \\
\text { of groin hernia } \\
\text { for whom } \\
\text { surgical } \\
\text { management was } \\
\text { judged } \\
\text { appropriate }\end{array}$ & Mesh technique & $\begin{array}{l}\text { Non-mesh } \\
\text { technique }\end{array}$ & $\begin{array}{l}\text { Duration of operation, 'opposite' } \\
\text { method initiated, conversion, } \\
\text { hematoma, seroma, wound/ } \\
\text { superficial infection, serious } \\
\text { complications, length of } \\
\text { postoperative hospital stay, time } \\
\text { to return to usual activities, } \\
\text { persisting pain, persisting } \\
\text { numbness, hernia recurrence, } \\
\text { known death }\end{array}$ & NA & s & NA \\
\hline $\begin{array}{l}\text { EU Hernia Trialists } \\
\text { Collaboration, } 2002 \\
\text { [39] }\end{array}$ & 35 & 6,901 & $\begin{array}{l}\text { Patients with } \\
\text { clinical diagnosis } \\
\text { of groin hernia } \\
\text { for whom } \\
\text { surgical }\end{array}$ & $\begin{array}{l}\text { Laparoscopic repair, } \\
\text { mesh methods }\end{array}$ & $\begin{array}{l}\text { Open repair, non- } \\
\text { mesh methods }\end{array}$ & Hernia recurrence, persisting pain & NA & S & NA \\
\hline
\end{tabular}


Table 1 Characteristics of the 22 identified surgical IPDMAs (Continued)

\begin{tabular}{|c|c|c|c|c|c|c|c|c|}
\hline & & & $\begin{array}{l}\text { management } \\
\text { judged } \\
\text { appropriate }\end{array}$ & & & & & \\
\hline $\begin{array}{l}\text { Gregson et al., } 2012 \\
\text { [40] }\end{array}$ & 8 & 2,186 & $\begin{array}{l}\text { Patients with } \\
\text { spontaneous } \\
\text { supratentorial } \\
\text { intracerebral } \\
\text { hemorrhage }\end{array}$ & Surgery & $\begin{array}{l}\text { Conservative } \\
\text { treatment }\end{array}$ & Unfavorable outcome & $\begin{array}{l}\text { Location of hematoma, time from NA } \\
\text { event, age, Glascow Coma Score, } \\
\text { volume of hematoma (5) }\end{array}$ & $4 / 5$ \\
\hline
\end{tabular}




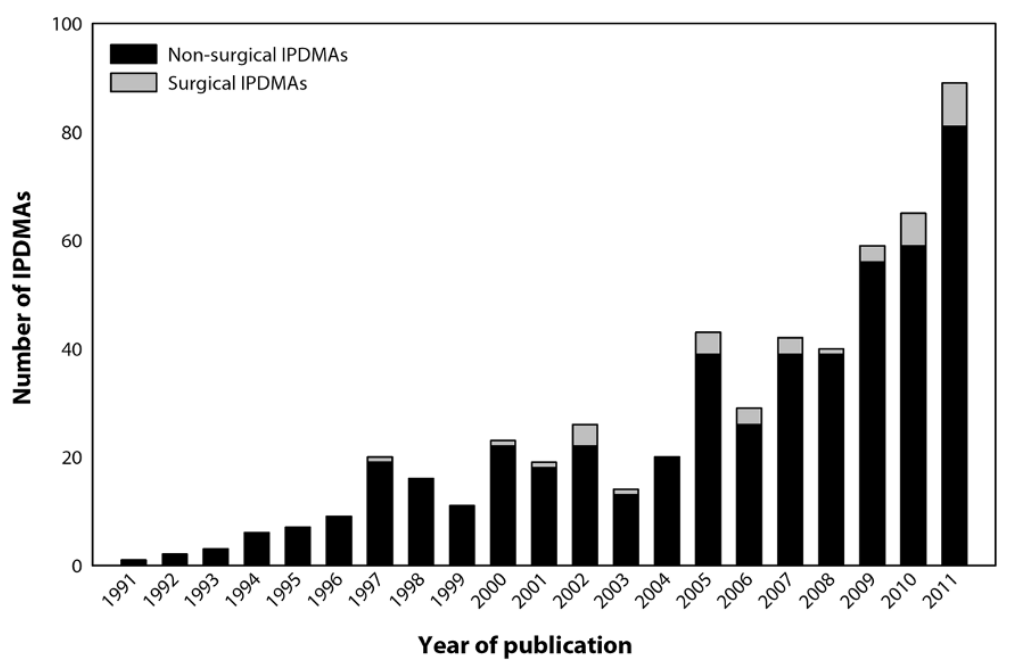

Figure 2 Number of applied IPDMA published up to April 2012,* as identified by a systematic review of PubMed, Embase, Web of Science, and the Cochrane Library. *Thirty-seven IPDMAs published in 2012 were identified up to 24 April 2012, when the review was conducted.

intervention versus in-hospital fibrinolysis. In three IPDMAs [30-32], comparing routine invasive strategies with selective invasive strategies in 5,467 patients with nonST segment elevation acute coronary syndromes, data from the same three trials (FRISC II, ICTUS, and RITA-3) were used. In addition, of the three IPDMAs that focused on inguinal hernia repair one IPDMA [39] presented a combination of the data used in the other two IPDMAs $[37,38]$.

\section{Number, justification, type, and methods of subgroups analyses in surgical IPDMAs}

In 18 (82\%) of the full set of surgical IPDMAs assessed, subgroup analyses were performed to examine whether certain patients benefit more from a specific treatment than others. The median number of subgroups reported in these IPDMAs was 3.5 (range, 1-16, IQR 5.25 (1.256.5)). In 12 (67\%) of the 18 surgical IPDMAs that studied subgroups a justification for subgroup analyses was mentioned. Scientific literature was used for justification in these studies.

The types of subgroups studied varied. Fifteen $(83 \%)$ IPDMAs studied patient characteristics, five (28\%) studied household characteristics, 15 (83\%) studied disease characteristics, and six (33\%) studied interventionrelated subgroups. Subgroups related to study or trial effects were studied in three (17\%) IPDMAs. No IPDMAs studied subgroups related to the quality of the included trials, for example concealment of allocation, blinding, or completeness of follow-up.

Twelve (55\%) IPDMAs stratified their analysis per trial before pooling the results (two-step analysis). A one-step analysis was performed in four (18\%) IPDMAs. Statistical methods for subgroup analyses were mentioned in 11 (61\%) of the 18 IPDMAs performing subgroup analyses. All IPDMAs that mentioned statistical methods for subgroup analysis used interaction tests.

Only five (28\%) surgical IPDMAs mentioned the power of the subgroup analyses. Three IPDMAs reported that their studies were underpowered to detect subgroup effects, one IPDMA reported that their study was well powered to detect subgroups effects, however, did fail to show differences in subgroups, and one IPDMA mentioned differences in power between different subgroups, but not whether these were over- or underpowered.

Eleven (61\%) of the 18 IPDMAs performing subgroup analyses reported a significant overall effect estimate, whereas six $(33 \%)$ reported a non-significant one. One IPDMA (6\%) did not report an overall effect estimate and only presented results of subgroup analyses [40].

Of the IPDMAs that reported non-significant overall results, three IPDMAs (50\%) reported significant results in one or more subgroup analyses. Results remained significant in one or more subgroups in eight of the IPDMAs (73\%) that reported a significant overall result.

Thirty-six (40\%) of the total number of 90 subgroups analyses were performed on a non-significant or inconclusive overall effect estimate, whereas 49 (54\%) were performed on a significant overall effect estimate. The remaining five (6\%) subgroups originated from the one IPDMA that did not report an overall effect estimate and only presented results of subgroup analyses, four out of these five subgroups being significant [40]. Of the subgroup analyses performed on nonsignificant overall results, five (14\%) became significant. Nine (18\%) of those performed on IPDMAs with a significant overall result remained significant. 
Eight (67\%) of the 12 surgical IPDMAs with significant subgroups reported on what the implications of these significant results of their subgroup analyses were for clinical practice. Mainly, the importance of differentiating when evaluating the efficacy and safety of new medical and interventional treatments, and translating these findings in treatment recommendations were emphasized. Moreover, it was reported that the influence of certain subgroups had not been reported previously, that findings concurred with recent recommendations or guidelines, and that subgroups not per se needed to be an exclusion criterion for treatment. Eight (44\%) of the 18 significant subgroups were implemented in clinical guidelines.

\section{Quality of reporting}

The quality of reporting of the surgical IPDMAs varied (Figure 3). More than half of the IPDMA failed to report whether or not there was a protocol for the IPDMA project available. The reason why the IPD approach was initiated and the numbers of patients within each of the original studies were generally well reported. For 17 (77\%) IPDMAs, the process used to identify relevant studies for the IPDMA were reported. Details on the statistical analysis were reported in 16 (73\%) IPDMAs, however, details on the identification process and statistical analysis were not described in one IPDMA (4\%), and were unclear in the remaining five (23\%) IPDMAs.

\section{Discussion}

Our systematic review of all IPDMAs on surgical interventions published so far provides an overview of the potential advantages of IPDMAs (see Table 2 for examples). In 18 (82\%) of the full set of 22 surgical IPDMAs assessed, subgroup analyses were performed to examine whether certain patients benefit more from a specific treatment than others. Eight (67\%) of the 12 surgical IPDMAs with significant subgroups reported on what the implications of their findings were for clinical practice. Forty-four percent (8 out of 18) of the significant subgroups were implemented in clinical guidelines.

Although many IPDMAs performed subgroup analyses, the overall treatment was usually the main focus of the paper. Only occasionally subgroup analyses were emphasized. In surgical IPDMAs, similar to IPDMAs in general [42], subgroups were often based on patient and disease characteristics. The median number of subgroups has been reported to range from 2 to 4 , the maximum number of subgroups from 15 to 50 [6,43-45], which is comparable to our findings. Justification of subgroup analyses, the methods used to perform subgroup analyses, and power calculations for performing subgroup analyses are often not reported in IPDMAs [6,43-48]. However, 11 (65\%) of the IPDMAs included in our study justified at least one of the subgroups on which they reported, scientific literature being the mode of justification used. This is in line with other studies that found that clinical experience or biochemical justification is rare $[44,46,49]$. Others showed that the proportion of studies that used interaction tests for at least one of their subgroups ranges from $10 \%$ to $56 \%[6,43-48]$, which is slightly lower compared to our findings. So far, few studies mentioned the importance of the power of subgroup analyses $[6,44,50,51]$, and reported that many

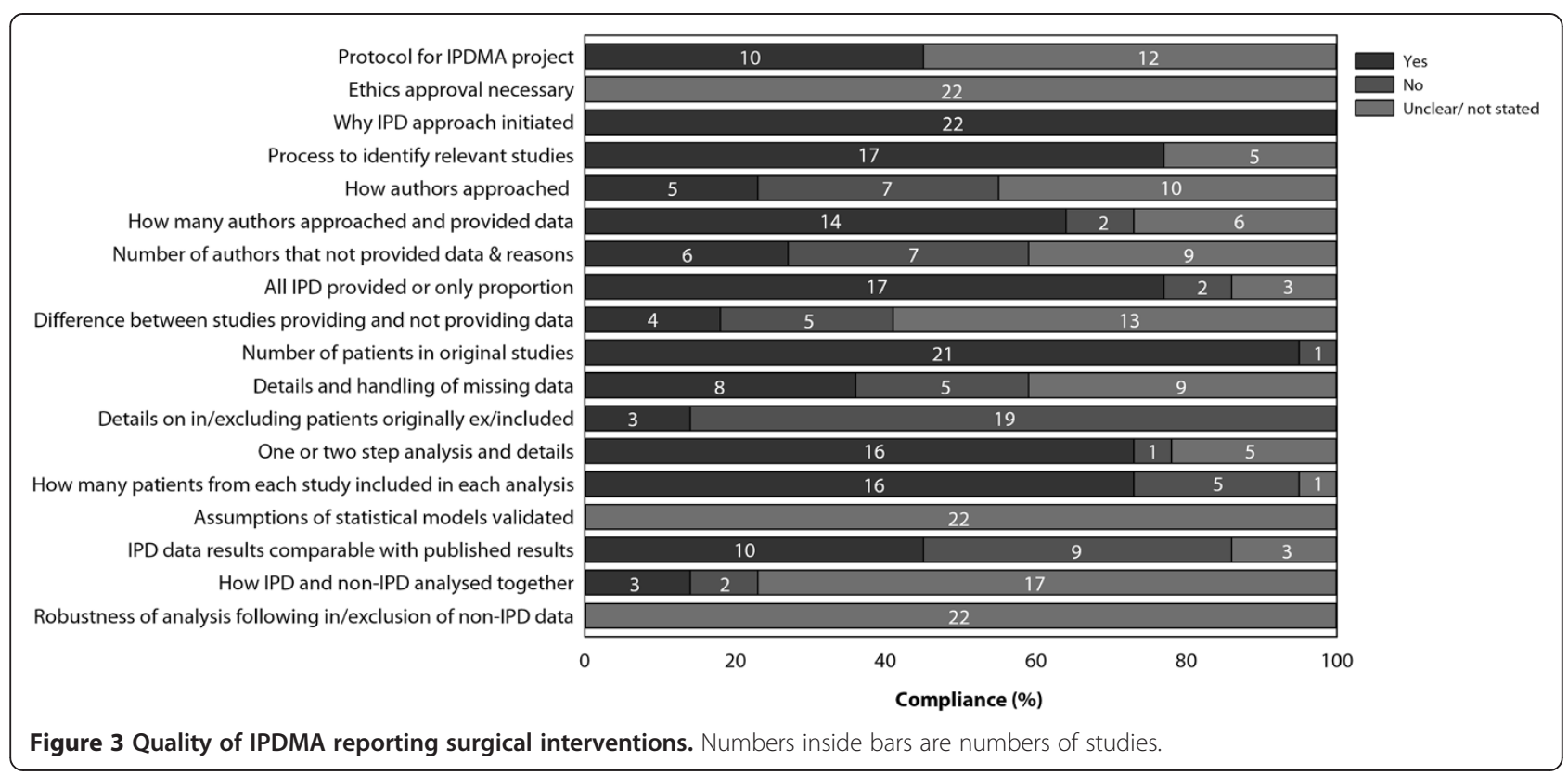




\section{Table 2 Two examples of differences in conclusions with regard to how patient-level characteristics modify treatment} effect

Example
Effectiveness of coronary artery bypass grafting vs. percutaneous
coronary interventions for multivessel disease.

\section{Description}

A two-step meta-analysis of individual patient data from 7,812 patients included in 10 randomized trials comparing coronary artery bypass grafting (CABG) and percutaneous coronary intervention $(\mathrm{PCl})$ in patients with multivessel coronary artery disease, showed a similar overall treatment effect on long-term mortality after CABG and PCI [20]. However, in diabetic patients mortality was substantially lower in the CABG group than in the PCl group (HR 0.70,95\% Cl 0.56-0.87). Mortality was similar between groups in patients without diabetes (HR 0.98,95\% $\mathrm{Cl}$ 0.86-1.12; $P=0.01$ for interaction). Patient age modified the effect of treatment on mortality with hazard ratios of 1.25 ( $95 \% \mathrm{Cl} 0.94-1.66)$ in patients aged $<55$ years, 0.90 (95\% Cl 0.75-1.09) in patients aged 55-64 years, and $0.82(95 \% \mathrm{Cl} 0.70-$ 0.97 ) in patients aged $\geq 65$ years ( $P=0.002$ for interaction). Treatment effect was not modified by other subgroups. CABG might be a better option for patients aged $\geq 65$ years and patients with diabetes since mortality was found to be lower in these subgroups. These results have been implemented in clinical guidelines [41].

Effectiveness of routine vs. selective invasive strategy in patients with non-ST-segment elevation acute coronary syndrome.
An individual patient data meta-analysis of three randomized trials of routine versus selective invasive strategies in patients with non-ST-segment elevation acute coronary syndrome showed that a routine invasive strategy resulted in significantly less cardiovascular deaths (CV deaths) or non-fatal myocardial infarctions (MIs) compared to selective invasive strategies [30]. The authors used patient's baseline characteristics to develop a multivariable risk prediction model. A simplified integer risk score was derived from the risk prediction model to predict a patient's 5-year probability of CV death or Ml, and the patients were categorized into three risk groups (low, intermediate, and high risk).

The treatment effect was similar between groups in patients with low-risk (HR 0.80 (95\% Cl 0.63-1.02)) and intermediate-risk (HR 0.81 (95\% Cl 0.66-1.01)) scores. In patients with high-risk scores treatment favored routine over selective invasive strategies (HR $0.68(95 \% \mathrm{Cl} 0.53-0.86)$ ). There were $2.0 \%(95 \% \mathrm{Cl}-4.1-0.1 \%)$ and $3.8 \%(95 \% \mathrm{Cl}-7.4--0.1 \%)$ absolute risk reductions in $\mathrm{CV}$ death or $\mathrm{Ml}$ in the lowand intermediate-risk groups and an $11.1 \%(95 \% \mathrm{Cl}-18.4--3.8 \%)$ absolute risk reduction in the highest-risk patients. The multivariable risk prediction model has not yet been implemented in clinical guidelines. reports put too much emphasis on subgroup analyses that commonly lacked statistical power. This is in agreement with the results of the present study.

To the best of our knowledge we are the first to study surgical IPDMAs, and illustrate the merits of this method within surgery. However, some potential limitations should also be discussed. First, our literature search for surgical IPDMAs was limited to IPDMAs with IPD obtained from RCTs comparing surgical interventions, excluding IPDMAs regarding drug-eluting medical devices and surgical trials in which a drug was the comparison, and records were limited to the English language. We, however, believe that our review provides a good representation of the method within the surgical field. Second, reporting bias could not be entirely excluded, since reporting of subgroup effects in scientific publications might be influenced by reviewers' and editors' opinions. Third, as most studies mentioned multiple subgroups, a clustering effect might occur for reporting on justification and statistical methods. Therefore, the results were reported on study level instead of individual subgroup level. Fourth, in the 12 IPDMAs of cardiovascular interventions reporting subgroup analyses, several studies included a same set of trials and the pattern of exploring heterogeneity among these studies might be similar, that is, there might be a clustering effect. As this might impact the subsequent analyses as well as the conclusion, we performed a sensitivity analysis. The outcomes and conclusions were not substantially influenced by the inclusion of studies using the same set of trials. Fifth, the time from publication to implementation of a result into a guideline or clinical practice can be highly variable, and sometimes takes even more than 10 years [52]. Most surgical IPDMAs included in the present study have only recently been published, and time to possible implementation has been rather short. Therefore, we might have underestimated the implementation of results from IPDMAs into guidelines and/or clinical practice.

\section{Conclusions}

One of the challenges in medicine is to rationally implement available therapies in clinical practice, in the appropriate patients at the appropriate time. Findings from IPDMAs might provide insight into opportunities to improve evidence-based treatment decisions for patients. 
IPDMA is an extremely powerful tool if used correctly and provides the most definitive synthesis of the available evidence, also for potential subgroups. Despite the recommendations available on reporting clinical trials and meta-analyses, such as PRISMA [18], these guidelines have not been specifically developed for IPDMAs. The development of a generally accepted guideline for reporting on IPDMAs including subgroup analyses should therefore be encouraged. This seems the only option to really improve the reporting, analyses, and claims and applicability of subgroup effects in clinical research.

\section{Additional files}

Additional file 1: Detailed search strategy.

Additional file 2: PRISMA 2009 Checklist.

Additional file 3: PRISMA 2009 Flow Diagram.

\section{Competing interests}

The authors declare that they have no competing interests.

\section{Authors' contributions}

GH prepared the protocol with guidance from $H G, C V L$, and MR. GH and MR developed the search strategies. GH and MR selected relevant studies and extracted data; all authors participated in screening/extraction for the initial unpublished version of the review. GH carried out the analysis and prepared the manuscript with input from all authors. All authors read and approved the final manuscript.

\section{Funding}

This research received no grant from any funding agency in the public, commercial or not-for-profit sectors.

\section{Author details}

${ }^{1}$ Department of Operating Rooms, Radboud University Nijmegen Medical Center, PO Box 9101, Nijmegen 6500HB, The Netherlands. ${ }^{2}$ Department of Surgery, Radboud University Nijmegen Medical Center, Nijmegen, The Netherlands. ${ }^{3}$ Department of Epidemiology, Biostatistics \& HTA, Radboud University Nijmegen Medical Center, Nijmegen, The Netherlands.

Received: 11 November 2012 Accepted: 14 June 2013

Published: 5 July 2013

\section{References}

1. McCulloch P: How to improve surgical research. BMJ 2011, 343:d4121.

2. Ergina PL, Cook JA, Blazeby JM, Boutron I, Clavien PA, Reeves BC, Seiler CM, Balliol C, Altman DG, Aronson JK, Barkun JS, Campbell WB, Cook JA, Feldman LS, Flum DR, Glasziou P, Maddern GJ, Marshall JC, McCulloch P, Nicholl J, Strasberg SM, Meakins JL, Ashby D, Black N, Bunker J, Burton M, Campbell M, Chalkidou K, Chalmers I, de Leval M, et al: Challenges in evaluating surgical innovation. Lancet 2009, 374:1097-1104.

3. Barkun JS, Aronson JK, Feldman LS, Maddern GJ, Strasberg SM, Balliol C, Altman DG, Blazeby JM, Boutron IC, Campbell WB, Clavien PA, Cook JA, Ergina PL, Flum DR, Glasziou P, Marshall JC, McCulloch P, Nicholl J, Reeves BC, Seiler CM, Meakins JL, Ashby D, Black N, Bunker J, Burton M, Campbell M, Chalkidou K, Chalmers I, de Leval M, et al: Evaluation and stages of surgical innovations. Lancet 2009, 374:1089-1096.

4. Sun X, Briel M, Busse JW, You JJ, Akl EA, Mejza F, Bala MM, Bassler D, Mertz D, Diaz-Granados N, Vandvik PO, Malaga G, Srinathan SK, Dahm P, Johnston BC, Alonso-Coello P, Hassouneh B, Walter SD, Heels-Ansdell D, Bhatnagar N, Altman DG, Guyatt GH: Credibility of claims of subgroup effects in randomised controlled trials: systematic review. BMJ 2012, 344:e1553.

5. Bachmann LM, Puhan MA, ter Riet G, Bossuyt PM: Sample sizes of studies on diagnostic accuracy: literature survey. BMJ 2006, 332:1127-1129.
6. Assmann SF, Pocock SJ, Enos LE, Kasten LE: Subgroup analysis and other (mis)uses of baseline data in clinical trials. Lancet 2000, 355:1064-1069.

7. Feinstein AR: The problem of cogent subgroups: a clinicostatistical tragedy. J Clin Epidemiol 1998, 51:297-299.

8. Brookes ST, Whitley E, Peters TJ, Mulheran PA, Egger M, Davey Smith G: Subgroup analyses in randomised controlled trials: quantifying the risks of false-positives and false-negatives. Health Technol Assess 2001, 5:1-56.

9. Rothwell PM: Treating individuals 2. Subgroup analysis in randomised controlled trials: importance, indications, and interpretation. Lancet 2005, 365:176-186.

10. Gabler NB, Duan N, Liao D, Elmore JG, Ganiats TG, Kravitz RL: Dealing with heterogeneity of treatment effects: is the literature up to the challenge? Trials 2009, 10:43.

11. Bender R, Koch A, Skipka G, Kaiser T, Lange S: No inconsistent trial assessments by NICE and IQWiG: different assessment goals may lead to different assessment results regarding subgroup analyses. $J$ Clin Epidemiol 2010, 63:1305-1307.

12. Riley RD, Lambert PC, Abo-Zaid G: Meta-analysis of individual participant data: rationale, conduct, and reporting. BMJ 2010, 340:c221.

13. Berlin JA, Santanna J, Schmid CH, Szczech LA, Feldman HI: Individual patient- versus group-level data meta-regressions for the investigation of treatment effect modifiers: ecological bias rears its ugly head. Stat Med 2002, 21:371-387.

14. Fisher DJ, Copas AJ, Tierney JF, Parmar MK: A critical review of methods for the assessment of patient-level interactions in individual participant data meta-analysis of randomized trials, and guidance for practitioners. J Clin Epidemiol 2011, 64:949-967.

15. Lambert PC, Sutton AJ, Abrams KR, Jones DR: A comparison of summary patient-level covariates in meta-regression with individual patient data meta-analysis. J Clin Epidemiol 2002, 55:86-94.

16. Tugwell $P$, Knottnerus JA: Advantages of individual patient data analysis in systematic reviews. J Clin Epidemiol 2010, 63:233-234.

17. van Walraven C: Individual patient meta-analysis-rewards and challenges. J Clin Epidemiol 2010, 63:235-237.

18. Moher D, Liberati A, Tetzlaff J, Altman DG: Preferred reporting items for systematic reviews and meta-analyses: the PRISMA statement. BMJ 2009, 339:b2535.

19. Jorgensen AL, Alfirevic Z, Tudur Smith C, Williamson PR: Cervical stitch (cerclage) for preventing pregnancy loss: individual patient data meta-analysis. BJOG 2007, 114:1460-1476.

20. Hlatky MA, Boothroyd DB, Bravata DM, Boersma E, Booth J, Brooks MM Carrie D, Clayton TC, Danchin N, Flather M, Hamm CW, Hueb WA, Kahler J, Kelsey SF, King SB, Kosinski AS, Lopes N, McDonald KM, Rodriguez A, Serruys P, Sigwart U, Stables RH, Owens DK, Pocock SJ: Coronary artery bypass surgery compared with percutaneous coronary interventions for multivessel disease: a collaborative analysis of individual patient data from ten randomised trials. Lancet 2009, 373:1190-1197.

21. Daniels JP, Middleton L, Xiong T, Champaneria R, Johnson NP, Lichten EM, Sutton C, Vercellini P, Gray R, Hills RK, Jones KD, Aimi G, Khan KS, International LUNA IPD Meta-analysis Collaborative Group: Individual patient data meta-analysis of randomized evidence to assess the effectiveness of laparoscopic uterosacral nerve ablation in chronic pelvic pain. Hum Reprod Update 2010, 16:568-576.

22. Burzotta F, De Vita M, Gu YL, Isshiki T, Lefevre T, Kaltoft A, Dudek D, Sardella G, Orrego PS, Antoniucci D, De Luca L, Biondi-Zoccai GG, Crea F, Zijlstra F: Clinical impact of thrombectomy in acute ST-elevation myocardial infarction: an individual patient-data pooled analysis of 11 trials. Eur Heart J 2009, 30:2193-2203.

23. Bonati LH, Dobson J, Algra A, Branchereau A, Chatellier G, Fraedrich G, Mali WP, Zeumer H, Brown MM, Mas JL, Ringleb PA: Short-term outcome after stenting versus endarterectomy for symptomatic carotid stenosis: a preplanned meta-analysis of individual patient data. Lancet 2010, 376:1062-1073.

24. Middleton LJ, Champaneria R, Daniels JP, Bhattacharya S, Cooper KG, Hilken NH, O'Donovan P, Gannon M, Gray R, Khan KS, International Heavy Menstrual Bleeding Individual Patient Data Meta-analysis Collaborative Group, Abbot J, Barrington J, Bhattacharya S, Bongers MY, Brun JL, Busfield R, Sowter M, Clark TJ, Cooper J, Cooper KG, Corson SL, Dickersin K, Dwyer N, Gannon M, Hawe J, Hurskainen R, Meyer WR, O'Connor H, Pinion S, et al: Hysterectomy, endometrial destruction, and levonorgestrel releasing intrauterine system (Mirena) for heavy menstrual bleeding: systematic 
review and meta-analysis of data from individual patients. BMJ 2010, 341:c3929.

25. Mercado N, Wijns W, Serruys PW, Sigwart U, Flather MD, Stables RH, O'Neill WW, Rodriguez A, Lemos PA, Hueb WA, Gersh BJ, Booth J, Boersma E: One-year outcomes of coronary artery bypass graft surgery versus percutaneous coronary intervention with multiple stenting for multisystem disease: a meta-analysis of individual patient data from randomized clinical trials. J Thorac Cardiovasc Surg 2005, 130:512-519.

26. Boersma E: Does time matter? A pooled analysis of randomized clinical trials comparing primary percutaneous coronary intervention and in-hospital fibrinolysis in acute myocardial infarction patients. Eur Heart J 2006, 27:779-788.

27. Timmer JR, Ottervanger JP, de Boer MJ, Boersma E, Grines CL, Westerhout CM, Simes RJ, Granger CB, Zijlstra F: Primary percutaneous coronary intervention compared with fibrinolysis for myocardial infarction in diabetes mellitus: results from the Primary Coronary Angioplasty vs Thrombolysis-2 trial. Arch Intern Med 2007, 167:1353-1359.

28. de Boer SP, Westerhout CM, Simes RJ, Granger CB, Zijlstra F, Boersma E: Mortality and morbidity reduction by primary percutaneous coronary intervention is independent of the patient's age. JACC Cardiovasc Interv 2010, 3:324-331.

29. de Boer SP, Barnes EH, Westerhout CM, Simes RJ, Granger CB, Kastrati A, Widimsky P, de Boer MJ, Zijlstra F, Boersma E: High-risk patients with ST-elevation myocardial infarction derive greatest absolute benefit from primary percutaneous coronary intervention: results from the Primary Coronary Angioplasty Trialist versus thrombolysis (PCAT)-2 collaboration. Am Heart J 2011, 161:500-507. e1.

30. Fox KA, Clayton TC, Damman P, Pocock SJ, de Winter RJ, Tijssen JG, Lagerqvist $B$, Wallentin $L$ : Long-term outcome of a routine versus selective invasive strategy in patients with non-ST-segment elevation acute coronary syndrome a meta-analysis of individual patient data. J Am Coll Cardiol 2010, 55:2435-2445.

31. Damman $P$, Clayton $T$, Wallentin L, Lagerqvist B, Fox KA, Hirsch A, Windhausen F, Swahn E, Pocock SJ, Tijssen JG, de Winter RJ: Effects of age on long-term outcomes after a routine invasive or selective invasive strategy in patients presenting with non-ST segment elevation acute coronary syndromes: a collaborative analysis of individual data from the FRISC II - ICTUS - RITA-3 (FIR) trials. Heart 2012, 98:207-213.

32. Damman $P$, Wallentin L, Fox KA, Windhausen F, Hirsch A, Clayton T, Pocock SJ, Lagerqvist B, Tijssen JG, de Winter RJ: Long-term cardiovascular mortality after procedure-related or spontaneous myocardial infarction in patients with non-ST-segment elevation acute coronary syndrome: a collaborative analysis of individual patient data from the FRISC II, ICTUS, and RITA-3 trials (FIR). Circulation 2012, 125:568-576.

33. Biau DJ, Katsahian S, Kartus J, Harilainen A, Feller JA, Sajovic M, Ejerhed L, Zaffagnini S, Ropke M, Nizard R: Patellar tendon versus hamstring tendon autografts for reconstructing the anterior cruciate ligament: a metaanalysis based on individual patient data. Am J Sports Med 2009, 37:2470-2478.

34. Rovers MM, Black N, Browning GG, Maw R, Zielhuis GA, Haggard MP: Grommets in otitis media with effusion: an individual patient data meta-analysis. Arch Dis Child 2005, 90:480-485.

35. Salerno F, Camma C, Enea M, Rossle M, Wong F: Transjugular intrahepatic portosystemic shunt for refractory ascites: a meta-analysis of individual patient data. Gastroenterology 2007, 133:825-834.

36. Staples MP, Kallmes DF, Comstock BA, Jarvik JG, Osborne RH, Heagerty PJ, Buchbinder R: Effectiveness of vertebroplasty using individual patient data from two randomised placebo controlled trials: meta-analysis. BMJ 2011, 343:d3952.

37. McCormack K, Scott NW, Go PM, Ross S, Grant AM: Laparoscopic techniques versus open techniques for inguinal hernia repair. Cochrane Database Syst Rev 2003, 1:CD001785.

38. Scott NW, McCormack K, Graham P, Go PM, Ross SJ, Grant AM: Open mesh versus non-mesh for repair of femoral and inguinal hernia. Cochrane Database Syst Rev 2002, 4:CD002197.

39. EU Hernia Trialists Collaboration: Repair of groin hernia with synthetic mesh: meta-analysis of randomized controlled trials. Ann Surg 2002, 235:322-332.

40. Gregson BA, Broderick JP, Auer LM, Batjer H, Chen XC, Juvela S, Morgenstern LB, Pantazis GC, Teernstra OP, Wang WZ, Zuccarello M, Mendelow AD: Individual patient data subgroup meta-analysis of surgery for spontaneous supratentorial intracerebral hemorrhage. Stroke 2012, 43:1496-1504.

41. CG126 Stable angina: NICE guideline. ; 2013 [http://guidance.nice.org.uk/ CG126/NICEGuidance].

42. Koopman L, van der Heijden GJ, Glasziou PP, Grobbee DE, Rovers MM: A systematic review of analytical methods used to study subgroups in (individual patient data) meta-analyses. J Clin Epidemiol 2007, 60:1002-1009.

43. Pocock SJ, Assmann SE, Enos LE, Kasten LE: Subgroup analysis, covariate adjustment and baseline comparisons in clinical trial reporting: current practice and problems. Stat Med 2002, 21:2917-2930.

44. Hernandez AV, Boersma E, Murray GD, Habbema JD, Steyerberg EW: Subgroup analyses in therapeutic cardiovascular clinical trials: are most of them misleading? Am Heart J 2006, 151:257-264.

45. Bhandari M, Devereaux PJ, Li P, Mah D, Lim K, Schunemann HJ, Tornetta P 3rd: Misuse of baseline comparison tests and subgroup analyses in surgical trials. Clin Orthop Relat Res 2006, 447:247-251.

46. Parker $A B$, Naylor $C D$ : Subgroups, treatment effects, and baseline risks: some lessons from major cardiovascular trials. Am Heart J 2000, 139:952-961.

47. Wang R, Lagakos SW, Ware JH, Hunter DJ, Drazen JM: Statistics in medicine-reporting of subgroup analyses in clinical trials. N Engl J Med 2007, 357:2189-2194.

48. Sun X, Heels-Ansdell D, Walter SD, Guyatt G, Spraque S, Bhandari M, Sanders D, Schemitsch E, Tornetta P 3rd, Swiontkowski M: Is a subgroup claim believable? A user's guide to subgroup analyses in the surgical literature. J Bone Joint Surg Am 2011, 93:e8.

49. Fernandez YGE, Nguyen H, Duan N, Gabler NB, Kravitz RL: Assessing Heterogeneity of Treatment Effects: Are Authors Misinterpreting Their Results. Health Serv Res 2010, 45:283-301.

50. Moreira ED Jr, Stein Z, Susser E: Reporting on methods of subgroup analysis in clinical trials: a survey of four scientific journals. Braz $J$ Med Biol Res 2001, 34:1441-1446.

51. Moreira ED, Susser E: Guidelines on how to assess the validity of results presented in subgroup analysis of clinical trials. Rev Hosp Clin Fac Med Sao Paulo 2002, 57:83-88.

52. Sheldon TA, Cullum N, Dawson D, Lankshear A, Lowson K, Watt I, West $P$, Wright $D$, Wright J: What's the evidence that NICE guidance has been implemented? Results from a national evaluation using time series analysis, audit of patients' notes, and interviews. BMJ 2004, 329:999.

doi:10.1186/2046-4053-2-52

Cite this article as: Hannink et al:: A systematic review of individual patient data meta-analyses on surgical interventions. Systematic Reviews 2013 2:52.

\section{Submit your next manuscript to BioMed Central and take full advantage of:}

- Convenient online submission

- Thorough peer review

- No space constraints or color figure charges

- Immediate publication on acceptance

- Inclusion in PubMed, CAS, Scopus and Google Scholar

- Research which is freely available for redistribution 